\title{
Development of the Biology Textbook of Process Evaluation and Learning Outcome for Students in Biology Education, University of Jambi
}

\section{Pengembangan Buku Ajar Evaluasi Proses dan Hasil Belajar Biologi Untuk Mahasiswa Prodi Pendidikan Biologi FKIP Universitas Jambi}

\author{
Ali Sadikin ${ }^{1)}$, Ferdiaz Saudagar ${ }^{2)}$, Fachruddiansyah Muslim ${ }^{3)}$ \\ ${ }^{1)}$ Teaching Staff of Biology Education Study Program FKIP Jambi University \\ ${ }^{2,3)}$ Teaching Staff at FKIP Jambi University \\ Correspondence Email: alisadikin@unja.ac.id
}

\begin{abstract}
The course of Evaluation Process and Learning Outcome in Biology Education University of Jambi has not been provided with neither student book nor modules as student guidance for the course lecturers. Therefore, I was interested in developing textbooks for this course with the aim of helping students to understand the subject in order to minimize misconceptions and incoherence form the course objectives. This study applied ADDIE model (Analyze, Design, Development, Implementation, and Evaluation). This study went through needs and materials analysis, product design, and product development by having product validation from experts and product implementation. In the product implementation, students as respondents were required to get feedback for product improvements; lastly, product evaluation then took place. The validation results from the experts show that Biology Textbook of Process Evaluation and Learning Outcome is significantly appropriate, as noted with the score of 83 . However, there is a suggestion for the textbook to improve the cover, typographical errors, layout and page numbering. The second validation results suggestions to add competence of material, number of pages, material explanation and bibliography. The product testing in a small group shows that the product is categorized as significantly appropriate with the score of 85.5. According to a student user, the product is good and handy due to its small size yet rich contents. Currently, the product, in the form of books, have been provided with ISBN, published and distributed to students and to Faculty of Teacher Training and Education and University of Jambi libraries. The books are currently in the process to be published in a large scale by Salim Media Indonesia Publisher.
\end{abstract}

\section{Keywords: Development, Biology Textbook of Process Evaluation and Learning Outcome}

Abstrak. Pembelajaran mata kuliah Evaluasi Proses dan Hasil Belajar Biologi di Prodi Pendidikan Biologi FKIP Universitas Jambi belum memiliki buku atau pun modul yang dapat digunakan sebagai pegangan mahasiswa dalam perkuliahan. Untuk itu lah saya tertarik untuk mengembangkan buku ajar mata kuliah ini dengan harapan dapat membantu mahasiswa dalam memahami materi mata kuliah tersebut supaya tidak terjadi kesalahan pemahaman dan keluar dari jalur atau tujuan pembelajaran. Penelitian ini menggunakan model pengembangan ADDIE (Analize, Design, Development, Implementation, Evaluation). Dalam penelitian ini melalui tahapan analisis kebutuhan dan materi, kemudian tahap desain produk yang diharapkan, kemudian menerima masukan dari evaluator materi dan evaluator media, kemudian pengembangan produk dan uji coba. Pada tahap uji coba prodak melibatkan responden dari mahasiswa untuk mendapatkan masukan dan kritikan terkait produk yang telah dibuat, terakhir tahap evaluasi dari uji coba yang telah dilakukan. Hasil validasi ahli menunjukkan bahwa buku ajar Evaluasi 
proses dan hasil pembelajaran biologi yang dikembangkan termasuk dalam kategori sangat layak untuk digunakan dengan skor 83. Namun masih mendapatkan masukan dari validator pertama berupa perbaikan tampilan cover, layout, kesalahan penulisan dan penomoran halaman. Kemudian masukan dari validator kedua memberikan kritikan dan masukan berupa kompetensi materi yang perlu ditambah, jumlah halaman yang perlu ditambah dan penjelasan materi serta daftar pustaka yang perlu ditambahkan. Hasil analisis pada uji coba kelompok kecil menunjukkan bahwa buku ajar yang dikembangkan termasuk dalam kategori baik ( 85,5). Menurut mahasiswa selaku pengguna produk buku ajar ini sudah baik dan cukup simpel dibawa kemana-mana karena ukurannya yang kecil dengan cakupan materi yang padat. Sekarang buku ajar mata kuliah Evaluasi proses dan hasil belajar biologi ini sudah dicetak dan sudah memiliki ISBN serta sudah disebarkan ke mahasiswa dan perpustakaan FKIP dan Perpustakaan Universitas Jambi, kemudian tahap penjajakan dengan penerbit Salim Media Indonesia untuk produksi skala besar dan pemasaran di toko buku-toko buku yang ada di Indonesia.

\section{Kata Kunci: Pengembangan, Buku Ajar Evaluasi dan Pembelajaran Biologi}

\section{INTRODUCTION}

Process Evaluation and Biology Learning Outcomes is one of the mandatory subjects for Biology Education students at Jambi University. This course contains concepts of measurement, assessment and evaluation, goals and benefits of evaluating learning outcomes, techniques for evaluating learning outcomes, principles of evaluating learning outcomes, domains of evaluating learning outcomes, key steps in evaluating learning outcomes, evaluation tools for learning outcomes, Techniques for preparing learning outcomes tests, Techniques for implementing learning outcomes tests, Question analysis techniques, Examination techniques, scoring, and processing of results, Techniques of giving learning achievement ranking and authentic assessment. This course also provides a basic concept of insight into the evaluation of biology learning processes and outcomes that an educator must possess (Risnita, 2004).

Good teaching materials will be adjusted to the appropriate learning models and methods with the competencies that will be delivered in the classroom (Sadikin A, 2017). Characteristics of teaching materials determine the choice of media in learning. The nature of teaching materials determines the form of assignments and learning experiences that will be given to students (Asyar, 2011) with the development of the times it is necessary to have a revolution and innovation in learning both learning models, assessment, and teaching materials (Mulyasa, E., Iskandar, D., \& Aryani, W. D. 2017). The development of the concept of assessing education at this time shows a broader direction. These concepts generally revolve around the view: (a) the assessment is not only directed at predetermined educational goals, but also to hide the goals, including side effects that may arise. (b) Assessment not only through measuring student behavior, but 
also by assessing educational components, both process input and output. (c) assessment is not only intended to determine whether or not the objectives have been set, but also to find out whether those goals are important for students and how students achieve them (d) considering the extent of the objectives and objects of assessment, the tools used in assessments are very diverse, not only limited to tests, but also assessment tools not tests. On that basis, the scope of the assessment objectives includes three main objectives, namely education programs, teaching-learning processes and learning outcomes (Risnita, 2005).

Educators must master and fulfill the three components of the professional trilogy, namely the basic components of science, professional substance, and professional practice components. Process Evaluation and Biology Learning Outcomes are expected to be able to empower educators to carry out professionalism duties according to the professional trilogy (Prastowo, 2012). The basic components of science provide a foundation for prospective educators so that they have insight, knowledge, skills, values, and attitudes regarding the teaching profession. Educators are required to master the science of education as the basis of their overall professional performance. The component of professional substance equips prospective educators with regard to what is in focus, as well as practical objects specific to their professional work. This component has core material learning a process which is part of the curriculum. The practice component directs prospective educators to carry out the practice of their profession to service targets appropriately and efficiently.

According to Regulation of the Minister of National Education no. 16 of 2007 the teacher must have four competencies which include pedagogic competence, professional competence, personality competence and social competence. One of the pedagogic competencies is that a teacher must be able to carry out assessments and evaluations correctly and precisely. The need for teaching materials Evaluation of the process and results of biology learning is increasingly high considering that there are no compulsory books or handbooks for this course. For this reason, the author ventured to develop this textbook as an answer to the needs of teaching materials for this course. Given the completeness of teaching materials will help in achieving learning goals (Suryani, N., Setiawan, A., \& Putria, A. 2018).

A good application of Assessment will be able to improve students' metacognitive abilities and learning motivation (Sadikin A, 2016; \& Sadikin A. 2018). Likewise with appropriate biology learning strategies will be able to improve student learning outcomes (Sadikin A, 2017). Biology learning is a vehicle for increasing knowledge, skills, attitudes and values and responsibilities to the environment, society, nations and countries that are faithful and devoted. Biology lessons are related to how to find out and understand about 
nature systematically so that biology learning is not only for mastering a collection of knowledge in the form of facts, concepts, principles but also a process of discovery so students are required to think critically and creatively.

According to Muhibbuddin (2010) to produce professional teachers is a difficult task that must be carried out by the education study program as an institution that plays a role in preparing teacher personnel. In preparing professional teacher candidates the lecture activities that equip prospective teachers, must show some relevant learning criteria, namely: (1) Prospective teachers need to be prepared to teach with appropriate strategies, plan and implement learning, develop and use media and learning resources with appropriate, and able to evaluate learning outcomes. (2) Lectures are more effective when embedded in learning experiences such as digging and processing information, not giving information. (3) Lecturers need to develop questioning skills to help skilled think about the material being studied, and generate the ability to ask questions. (4) The lecture strategy needs to be directed at building awareness of the difficulties of conception, practicing skills, fostering an attitude of curiosity, and building motivation for learning. It must be realized that experience in lectures tends to be scarce and imitated in carrying out their duties as a teacher later.

Learning evaluation is one of the most important aspects and cannot be separated from learning activities. The implementation of learning evaluation conducted by the teacher as an evaluator must be in accordance with the planned learning objectives in the lesson plan and learning activities that have been carried out. (Hasanah, U., Prasetyo, T. I., \& Lukiati, B. 2015).

\section{METHODOLOGY}

This research is a development research known as Research and Development. According to Sugiyono (2013) research and development is a research method used to produce certain products, and test the effectiveness of these products. In addition, according to Setyosari (2012) development research is a process used to develop and validate educational products. A product that will be developed in this study is a book entitled Process Evaluation and Learning Outcomes Biology for students of Biology Education Study Program Guidance and Counseling University of Jambi.

In the process of developing the textbook, the ADDIE development model is used which consists of 5 stages of activity (analysis, design, development, implementation, evaluation) (Rusdi, 2018). The basic consideration for choosing this model is because the development steps are more flexible, relatively simple, and in accordance with the type of 
final product to be developed. The five stages of development with the ADDIE model can be described in the form of a flow diagram as follows:

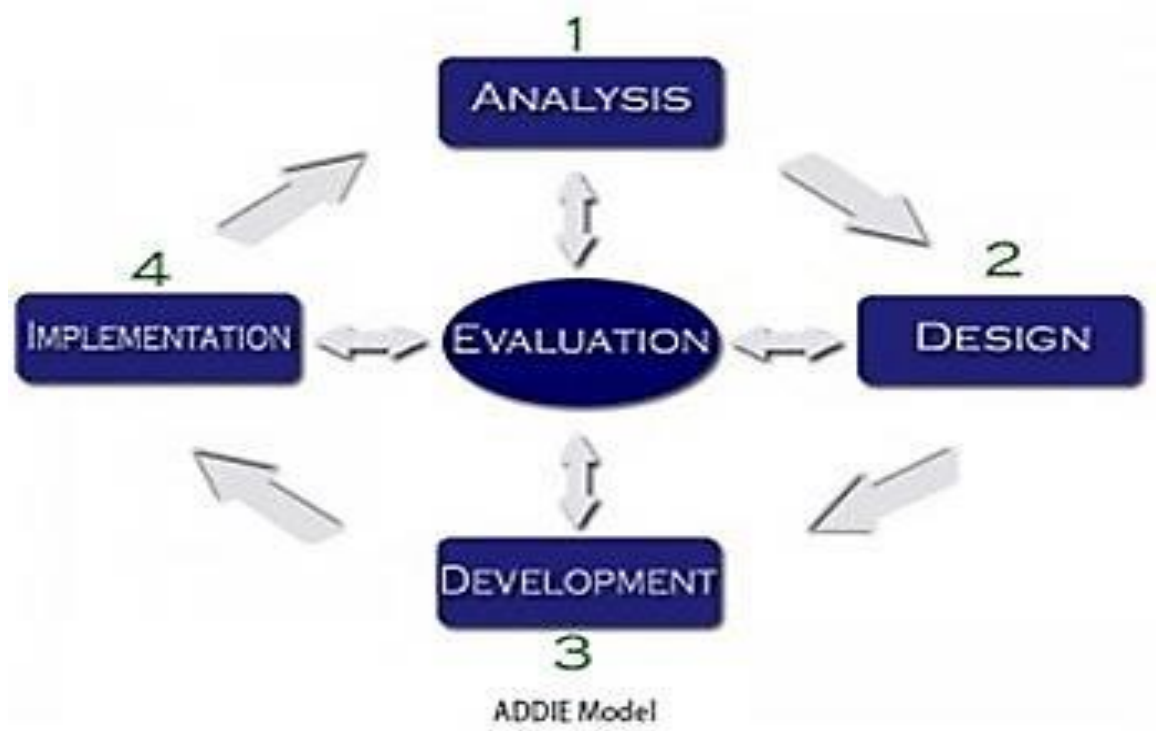

Figure 1. ADDIE Model Flow Chart

\section{RESULTS AND DISCUSSION}

The interim results of this development are in the form of an initial draft textbook on the Process Evaluation and Biological Learning Outcomes. After the product is finished, it is then validated, and then revised according to expert advice. The results of the first validation carried out by an expert as the evaluator in this research, Prof. Dr. Dra. Hj. Asni Johari, M.Sc, which validated the result twice. The results of expert validation of the textbooks developed are as follows.

Table 5.1 results of expert validation of textbooks developed

\begin{tabular}{|c|c|c|c|}
\hline No & Validation & Score & Information \\
\hline 1 & First & 76 & Not valid \\
\hline 2 & Second & 83 & Valid \\
\hline
\end{tabular}




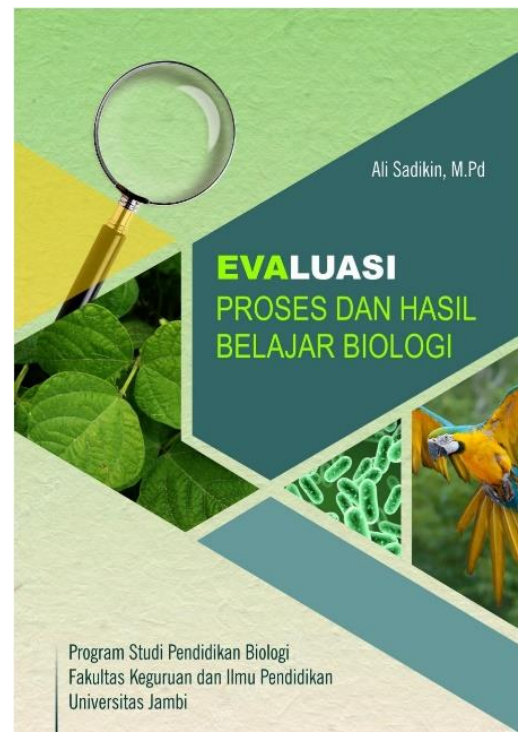

Figure 2. Validated Book Cover

The suggestions for improvement from the valuator for each aspect of the development of textbooks can be seen in Table 5.1.

Table 5.1 Suggestions for Product Improvement by Valuator in the first validation

\begin{tabular}{|c|c|c|c|}
\hline No. & Rated Aspect & Repair Suggestion & Revision \\
\hline 1. & $\begin{array}{l}\text { The complete book } \\
\text { component is in accordance } \\
\text { with the rules for preparing to } \\
\text { teach books }\end{array}$ & $\begin{array}{l}\text { Make a table of contents } \\
\text { properly and correctly to } \\
\text { describe the contents of the } \\
\text { book }\end{array}$ & $\begin{array}{l}\text { Repaired according to the } \\
\text { evaluator's suggestion by } \\
\text { making the correct table of } \\
\text { contents }\end{array}$ \\
\hline 2. & $\begin{array}{l}\text { The fonts used are consistent } \\
\text { and clear to read. }\end{array}$ & $\begin{array}{l}\text { Choose letters that are easy } \\
\text { to read and consistent }\end{array}$ & $\begin{array}{l}\text { Repaired according to the } \\
\text { evaluator's suggestion }\end{array}$ \\
\hline 3. & $\begin{array}{l}\text { The font size used is } \\
\text { appropriate and clear to read. }\end{array}$ & $\begin{array}{l}\text { Font size needs to be } \\
\text { adjusted so that it is easy to } \\
\text { read }\end{array}$ & $\begin{array}{l}\text { Repaired according to } \\
\text { suggestions. }\end{array}$ \\
\hline 4. & $\begin{array}{l}\text { The image displayed is in } \\
\text { accordance with the text }\end{array}$ & Already appropriate & There are no revisions \\
\hline 5. & $\begin{array}{l}\text { The image size is appropriate } \\
\text { and quite clearly seen }\end{array}$ & Images are sized at all & Image size corrected \\
\hline 6. & $\begin{array}{l}\text { The image shown helps } \\
\text { explain the material }\end{array}$ & $\begin{array}{l}\text { Each picture must be given } \\
\text { information so that the } \\
\text { reader is easier to } \\
\text { understand }\end{array}$ & All images are captioned \\
\hline 7. & $\begin{array}{l}\text { The color composition used is } \\
\text { interesting }\end{array}$ & $\begin{array}{l}\text { The color composition need } \\
\text { s to be improved }\end{array}$ & $\begin{array}{l}\text { Repaired according to the } \\
\text { evaluator's suggestion }\end{array}$ \\
\hline 8. & $\begin{array}{l}\text { Proportional and attractive } \\
\text { design layout. }\end{array}$ & $\begin{array}{l}\text { Improve writing of page } \\
\text { book }\end{array}$ & $\begin{array}{l}\text { The book pages are created } \\
\text { using footers }\end{array}$ \\
\hline 9. & $\begin{array}{l}\text { The material presented is in } \\
\text { accordance with the } \\
\text { competencies to be achieved. }\end{array}$ & Already appropriate & There are no revisions. \\
\hline 10. & $\begin{array}{l}\text { The material presented in } \\
\text { accordance with the } \\
\text { curriculum used. }\end{array}$ & Already appropriate. & There are no revisions \\
\hline 11. & $\begin{array}{l}\text { The material presented is } \\
\text { complete. }\end{array}$ & Already appropriate & No need to be revised \\
\hline 12. & $\begin{array}{l}\text { Material is presented } \\
\text { systematically. }\end{array}$ & $\begin{array}{l}\text { Material needs to be sorted } \\
\text { according to competence }\end{array}$ & $\begin{array}{l}\text { The material is sorted } \\
\text { according to suggestions }\end{array}$ \\
\hline
\end{tabular}




\begin{tabular}{cllc}
\hline No. & Rated Aspect & \multicolumn{1}{c}{ Repair Suggestion } & \multicolumn{1}{c}{ Revision } \\
\hline 13. & $\begin{array}{l}\text { Textbooks are predicted to be } \\
\text { able to encourage increased } \\
\text { student motivation }\end{array}$ & $\begin{array}{l}\text { Yes, existing activities can } \\
\text { encourage the improvement } \\
\text { of student motivation }\end{array}$ & There are no revisions \\
\hline
\end{tabular}

Inputs from the first validation include improvements to the table of contents, selection of fonts, font size, images, and book numbering. The second validation input is as follows:

Table 5.1 Suggestions for Product Improvement by Valuator in the second validation

\begin{tabular}{|c|c|c|c|}
\hline No. & Rated Aspect & Repair Suggestion & Revision \\
\hline 1. & $\begin{array}{l}\text { The complete book component is in } \\
\text { accordance with the rules for preparing } \\
\text { to teach books }\end{array}$ & Already appropriate. & There are no revisions \\
\hline 2. & $\begin{array}{l}\text { The fonts used are consistent and clear to } \\
\text { read }\end{array}$ & Fonts are consistent. & There are no revisions \\
\hline 3. & $\begin{array}{l}\text { The font size used is appropriate and } \\
\text { clear to read }\end{array}$ & $\begin{array}{l}\text { The font size is clear } \\
\text { enough to read }\end{array}$ & There are no revisions \\
\hline 4. & $\begin{array}{l}\text { The image displayed is in accordance } \\
\text { with the text. }\end{array}$ & Already appropriate & There are no revisions \\
\hline 5. & $\begin{array}{l}\text { The image size is appropriate and quite } \\
\text { clearly seen }\end{array}$ & Already appropriate. & There are no revisions \\
\hline 6. & $\begin{array}{l}\text { The image shown helps explain the } \\
\text { material. }\end{array}$ & Already appropriate & There are no revisions \\
\hline 7. & The color composition used is interesting & Already appropriate & There are no revisions \\
\hline 8. & Proportional and attractive design layout. & Yes, proportional & There are no revisions \\
\hline 9. & $\begin{array}{l}\text { The material presented is in accordance } \\
\text { with the competencies to be achieved. }\end{array}$ & Already appropriate & There are no revisions \\
\hline 10. & $\begin{array}{l}\text { The material presented in accordance } \\
\text { with the curriculum used }\end{array}$ & Already appropriate & There are no revisions \\
\hline 11. & The material presented is complete & Already appropriate & There are no revisions \\
\hline 12. & Material is presented systematically & Already appropriate & There are no revisions \\
\hline 13. & $\begin{array}{l}\text { Textbooks are predicted to be able to } \\
\text { encourage increased student motivation }\end{array}$ & $\begin{array}{l}\text { Yes, existing } \\
\text { activities can } \\
\text { encourage the } \\
\text { improvement } \\
\text { of student motivation }\end{array}$ & There are no revisions. \\
\hline
\end{tabular}




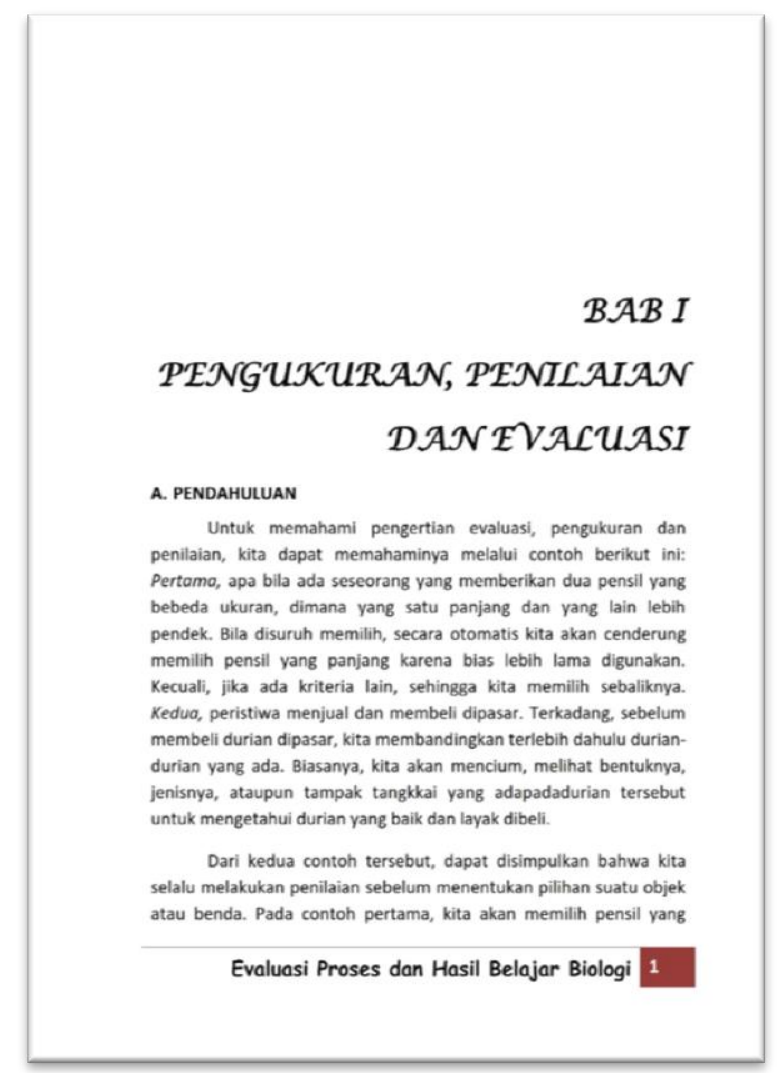

Figure 3. Parts of fixed contents

\subsection{Test Results Data}

The trials carried out began with small group trials, and then continued with large group trials. Once the product is revised according to the expert advice that performs validation, then the small group trial involving 6 college students to obtain input and feedback in order to improve the quality of the developed product. Data trial results were compiled using student feedback questionnaire with questions that the answer choices "Yes" or "No" accompanied by the reasons for each answer. The student answers as input to improve the products developed, comments and suggestions is most students are presented in T able 5.2

Table 5.2 Student Response Data on Textbooks in Examination Ex. Small

\begin{tabular}{|c|c|c|c|}
\hline No. & Name & $\%$ & Overall comments and input \\
\hline 1. & RS & 92 (very good) & $\begin{array}{l}\text { This book is very good. I find it easier to learn the basic foundation and } \\
\text { process of learning biology. }\end{array}$ \\
\hline 2. & AS & 87,5 (very good) & $\begin{array}{l}\text { This book looks interesting and is quite helpful in understanding the } \\
\text { material. My advice, add more images to make it easier to understand. }\end{array}$ \\
\hline 3. & $\mathrm{ES}$ & 75 (good) & $\begin{array}{l}\text { Books are very good, learning becomes easy to understand. But even } \\
\text { better if added activities for students }\end{array}$ \\
\hline 4. & $\mathrm{AH}$ & 87,5 (very good) & This book is very good. So more motivated to learn \\
\hline 5. & RKD & 62,5 (very good) & $\begin{array}{l}\text { The book is actually pretty good, but there are still flaws, the creation } \\
\text { hasn't motivated me to learn it. }\end{array}$ \\
\hline 6. & $\mathrm{HM}$ & 87,5 (very good) & $\begin{array}{l}\text { This book is good and complete. But the size of the book should be } \\
\text { enlarged so it is not too thick }\end{array}$ \\
\hline
\end{tabular}




\subsection{Data Analysis}

\subsubsection{Data Analysis of Validation Results}

Validation of Process Validation and Learning Outcomes Biology Learning textbook products produces data in the form of suggestions and input from experts to improve the quality of textbooks developed, and determine the feasibility of the textbook. Suggestions and inputs provided by experts are used as the basis for product revisions to produce the best products.

The expert's suggestions and input, among other things, according to the expert, the book must be completed with the author's biography, do not use too many types of letters, the image size is relatively the same, all images must be explained to be easier to understand, the tables are colored to be more interesting, writing the pages of the book were improved to make it more attractive, teaching aids were incomplete and for laboratory management materials to be arranged more systematically. All of the suggestions and inputs the author received for the sake of producing a decent and good textbook.

\subsubsection{Analysis s Small Group Test Results Data}

In this study, to obtain advice and input is most students to the products that have been developed, conducted a small group trial involving 6 College students. Trials this lasted for approximately 60 minutes, an hour outside of study. These trials by Student College read some of the material in the textbook. After that, all students were asked to fill out a questionnaire and provide suggestions and input that would be used as improvement material before the product was tested on a wider scale.

Questionnaire responses are college students consisting of 10 questions to choice the answer is "Yes" or "No" and why. From 6 college students, six of whom showed a positive response, one percentage is $100 \%$ (very good), $387.5 \%$ (good), and 1 to $75 \%$ (good), while one showed a negative response with a percentage of $62.5 \%$ (not good). The suggestions given by students include adding more pictures so that students are easier to understand the material, adding activities for students to be more enthusiastic in learning, then the size of the book to be enlarged, so that the book is not too many pages. The authors received these suggestions for later revisions. After the final revision of this 
textbook was printed and the ISBN was registered to the national library and distributed to students and libraries at Jambi University.

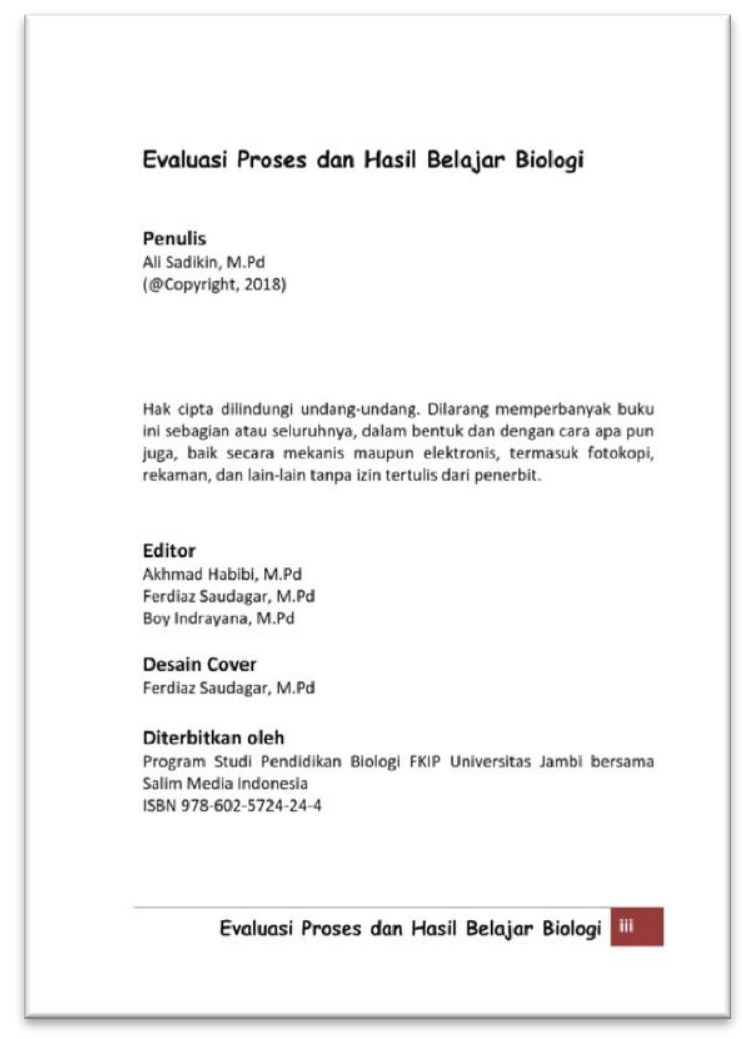

Figure 4. Book has been printed and has an ISBN

\section{CONCLUSIONS}

\section{AND RECOMMENDATIONS}

\section{Conclusion}

The conclusions from this study include:

1. The results of expert validation indicate that the evolution Process and Biology Learning Outcomes textbooks developed are feasible to use.

2. The results of the analysis of the small group trials show that the developed textbooks are included in the good category (85.5).

3. This book has been printed and ISBN and then distributed to students as a handle and distributed to the library of Faculty of Teacher Training and Education and Jambi University. 


\section{Recommendations}

Suggestions in this study are as follows.

1 The developed textbook can be tested for its effectiveness on several variables, for example, learning activeness, learning motivation, or student learning outcomes.

2 Textbooks can be developed in forms other than print, such as $e$-books or in the form of digital books for practical use

\section{REFERENCE}

Asyhar, R. (2011). Kreatif mengembangkan media pembelajaran. Jakarta: Gaung Persada.

Hasanah, U., Prasetyo, T. I., \& Lukiati, B. (2015). Analisis pelaksanaan evaluasi pembelajaran Biologi Kelas X semester genap 2013/2014 di SMAN Kota Blitar. Jurnal Pendidikan Biologi, 7(1), 39-46. Retrieved from http://journal2.um.ac.id/index.php/jpb/article/view/716/449

Muhibbuddin. (2010). Guru sebagai jabatan profesional: Handout. Banda Aceh: FKIP Unsyiah.

Mulyasa, E., Iskandar, D., \& Aryani, W. D. (2017). Revolusi dan inovasi pembelajaran sesuai standar proses. Bandung: PT. Remaja Rosda Karya.

Prastowo, A. (2012). Panduan kreatif membuat bahan ajar inovatif. Yogyakarta: Diva Press.

Risnita. (2004). Evaluasi pembelajaran. Jambi: IAIN STS Jambi.

Rusdi, M. (2018). Penelitian desain dan pengembangan kependidikan: Konsep, prosedur, dan sintesis pengetahuan baru. Depok: RajaGrafindo Persada.

Setyosari, P. (2012). Metode penelitian pendidikan dan pengembangan (4th ed.). Jakarta: Prenada Media.

Sugiyono. (2013). Metode penelitian kuantitatif, kualitatif, dan R\&D. Bandung: Alfabeta.

Sadikin, A. (2017). Dasar-dasar dan proses pembelajaran Biologi. Jambi: CV Salim Media Indonesia

Sadikin, A. (2018). Evaluasi proses dan hasil belajar Biologi. Jambi: CV. Salim Media Indonesia.

Sadikin, A. (2015). Hubungan EQ (emotional quotient) dengan hasil belajar mahasiswa Biologi semester ganjil tahun ajaran 2014/2015. Jurnal BIODIK, 1(1), 1-12. 
Sadikin, A. (2016). Penerapan asesmen berbasis portofolio dan jurnal belajar untuk meningkatkan kemampuan metakognitif dan motivasi belajar mahasiswa pada mata kuliah Perencanaan Pengajaran Biologi. Jurnal BIODIK, 2(2), 50-61.

Sadikin, A. (2017). Pengaruh penerapan strategi pembelajaran Rotating Trio Exchange terhadap hasil belajar mata kuliah Dasar - Dasar dan Proses Pembelajaran Biologi. Jurnal BIODIK, 3(2), 74-82.

Sadikin, A. (2018). Penerapan jurnal belajar untuk meningkatkan motivasi belajar mahasiswa pada mata kuliah Dasar - Dasar dan Proses Pembelajaran Biologi. Bioeducation Journal, 2(1), 70-75.

Suryani, N., Setiawan, A., \& Putria, A. (2018). Media pembelajaran inovatif dan pengembangannya. Bandung: PT. Remaja Rosdakarya 